\title{
Cultural Orientation and Reporting Channels: Experimental Study of Whistleblowing Intentions
}

\author{
ROMAITO SITUMEANG \\ INTIYAS UTAMI \\ UKSW Salatiga \\ I GEDE CAHYADI PUTRA \\ Universitas Mahasaraswati Denpasar
}

\begin{abstract}
Individualism refers to personal interests, while collectivism refers to collective interests. Formal and informal reporting channels are accessible to report wrongdoings. This research aims to test the causality effect between cultural orientation and whistleblowing intention, between reporting channel to whistleblowing intention, and the interaction effect between cultural orientation and reporting channel to whistleblowing intention. This research use $2 \times 2$ between subjects' factorial design. The manipulation of this research is the cultural orientation (individualism and collectivism) and reporting channels (formal and informal). The subjects in this research are accounting students of two private universities in Central Java and Bali. The variable measured is whistleblowing intention. The results of the test of the main effect show that cultural orientation affects the intention to complain about fraud. The testing of other main effects shows that the reporting channel affects whistleblowing intention. Testing the interaction effect shows that cultural orientation influences the intentions of whistleblowing intention, depending on the reporting channels provided.
\end{abstract}

Keywords: cultural orientation, reporting channel, whistleblowing

Abstrak - Budaya individualisme memiliki ciri mengacu kepada kepentingan pribadi sedangkan budaya kolektivisme mengacu kepada kepentingan kelompok. Jalur pelaporan formal dan informal adalah akses untuk melaporkan tindakan kecurangan. Tujuan penelitian ini untuk menguji hubungan kausalitas antara orientasi budaya dan niat aduan kecurangan, antara jalur pelaporan dan niat aduan kecurangan dan menguji efek interaksi antara orientasi budaya, jalur pelaporan dan niat aduan kecurangan. Penelitian ini menggunakan desain eksperimental $2 \times 2$ between subject. Subjek eksperimen adalah mahasiswa akuntansi dari dua perguruan tinggi swasta di Jawa Tengah dan di Bali. Variabel yang dimanipulasi yaitu orientasi budaya (individualisme dan kolektivisme) dan jalur pelaporan (formal dan informal). Variabel yang diukur adalah niat aduan kecurangan. Hasil pengujian efek utama menunjukkan bahwa orientasi budaya berpengaruh terhadap niat aduan kecurangan. Pengujian efek utama yang lain menunjukkan bahwa jalur pelaporan berpengaruh terhadap niat aduan kecurangan. Pengujian efek interaksi menunjukkan bahwa orientasi budaya

* Corresponding author: intiyas@staff.uksw.edu 
mempengaruhi niat aduan kecurangan tergantung pada jalur pelaporan yang disediakan.

Kata Kunci: Orientasi Budaya, Jalur Pelaporan, Aduan kecurangan

\section{Introduction}

Whistleblowing is a mechanism for disclosing fraud that occurs in an organization. Coffin (2003) stated that three-quarters of employees commit fraud in their companies. However, often persons or employees who are aware of the frauds do not want to report them (Miceli and Near, 1992). Employee tips are the most common method to express fraud (ACFE, 2018; Dyck, Morse, and Zingales, 2010). Whistleblowing is an effective mechanism for detecting fraud (Delloitte Forensic Center, 2010; KPMG, 2010), and the accounting profession plays a vital role in the whistleblowing process. Research on whistleblowing in accounting not only presents variations in various characteristic perspectives but also needs to be tested for supporting factors. A whistleblower can report misconduct to internal parties with formal channels or to external parties. However, the courage of the whistleblower needs to support the organizational culture so that fraud can be detected, and individuals do not retaliate. This condition is the motivation of this research.

Although retaliation and dismissal are potentially suffered by the reporter of fraud, a corrective action done by the reporter of fraud is essential to increase an organization's effectiveness that can lead to confidence towards the organization (Miceli and Near, 1992). Mapping research by Near and Miceli (1995), Gao and Brink (2017) show that determinants of whistleblowing intention are grouped into characteristics of the whistleblower, the report recipient, characteristics of the wrongdoers, characteristics of wrongdoing, and characteristics of the organization.

It is important that those who know about whistleblowing in an organization feel free to report any acts of fraud and gain support from the top management (Enz, 1988; Miceli et al., 2006). Support of organizations is essential for individuals that often dubbed as whistleblowers who potentially report the acts of fraud, especially if the frauds directly involve superiors (Near and Miceli, 1987). Therefore, whistleblowing is 
considered by many countries as a way to guarantee ethical behavior so that regulations have been made to strengthen whistleblowing measures such as the two provisions in Sarbanes Oxley Act 2002 and provisions that are enforced in U.S. (Schmidt, 2005).

Sherron Watkins is one of the whistleblowers who became the 2002 edition of Time Magazine's Three Persons of the Year (House et al., 2004). Sherron Watkins became a whistleblower in the case of Enron, an energy company in the United States. Sherron Watkins joined Enron in late 1993 while serving as vice president of Enron, Sherron reported manipulation of financial statements by sending an e-mail to Enron's President Director, Kenneth Lay. However, Kenneth Lay did not respond to the letter of Sherron Watkins, which ended in Enron's bankruptcy in 2001. The very popular Enron case underlies the emergence of the Sarbanes-Oxley Act (SOx), regulating the protection of whistleblowers.

Research conducted by Lestari and Yaya (2017) mentions factors that influence one's intention to do whistleblowing based on individual conditions, namely, internal locus of control, organizational commitment, and personal cost. Vinancia, Utami, and Nafsiah (2019) also found that personal cost influences whistleblowing intention. Several previous studies have examined the factors that influence whistleblowing intentions, such as the pressure of obedience and trust in the leadership (Setianto et al., 2016), behavioral perspectives (Miceli and Dozier, 1985), corporate ethics and culture (Pascoe and Welsh, 2010), subjective norms (Trongmateerut and Sweeney, 2013), cultural and behavioral orientations (Park, Blenkinsopp, Oktem and Omurgonulsen, 2008) and cultural dimensions (Tavakoli et al., 2003). The research done by Park et al. (2008) found a relationship between whistleblowing and culture, impacting one's attitude to report a fraud.

Tavakoli et al. (2003) conducted an empirical study about culture and whistleblowing in Croatia and the USA using Hofstede's cultural dimension, emphasizing that culture is essential because it is an input for a person to have a whistleblowing intention. The results of the research show that Croatia will avoid confrontation. It will choose to compromise or negotiate when it faces a conflict, a contradictory approach compared to the USA. 
Park et al. (2008) conducted researches in three countries regarding whistleblowing with the influence of cultural orientation and attitude. This research proposes a whistleblowing typology based on three dimensions of reporting channels for individuals: formal versus informal, identified versus anonymous, and internal versus external. The results obtained regarding the orientation of individualism and collectivism in each country are different. The research of Park et al. (2008) is consistent with Hofstede's (1980) research, which shows that South Korea leads to collectivist culture. England leads to individualistic culture, and Turkey leads to both cultures.

To understand the development of whistleblowing in a country such as Indonesia, it is done by observing the corruption cases (Lestari and Yaya, 2017). The survey of ACFE (2017) stated that the highest fraud phenomenon in Indonesia is corruption, with a percentage of $67 \%$. Corruption is the most detrimental type of fraud, with the highest percentage of 77\% involving 178 cases. However, Lestari and Yaya (2017) stated that Indonesia is experiencing an increase in corruption eradication efforts judged by public sector organizations that began implementing whistleblowing systems.

The development of whistleblowing in a country can also be seen in the country's culture. Keenan's research (2007) compared Chinese and American managers concerning whistleblowing, individual perceptions, and whistleblowing's organizational and moral tendencies. The results suggest that Chinese managers have a less positive perception of whistleblowing than American managers. This is because China adheres to a culture of collectivism while America adheres to a culture of individualism, and this result is consistent with previous researches. Thus, cultural differentiation affects individual whistleblowing intentions (Keenan, 2007).

From those phenomena and previous research, this research will be conducted to determine whether cultural differentiation and reporting channels influence whistleblowing intentions in a person using experimental methods. From those phenomena, this research was conducted in Indonesia by providing special treatment to subjects to feel the interaction between individualism and collectivism cultures by linking formal and informal reporting channels that influence one's whistleblowing intentions. 


\section{Theoretical Framework and Hypothesis Development}

\subsection{Whistleblowing Intention}

Whistleblowing is the disclosure of illegal, immoral, or illegitimate actions by employees or former employees controlled by the supervisor(s) (Miceli and Near, 1992). An employee has a great opportunity to be a whistleblower when he/she is aware and can see that his/her manager does deviate from the value that he believes (Near and Miceli, 1985). Hoffman and McNulty (2010) said that whistleblowing action could be justified if the whistleblower knows that an illegal action exists and needs to be reported to be followed up. There are several considerations for whistleblowers to report illegal actions, i.e., consideration about retaliation against whistleblowers as the reporters of illegal actions; consideration of whether other people also consider that the illegal actions that are reported by whistleblowers are indeed a violation of existing rules and against the public interest; consideration of whether the reporting of frauds or illegal activities can cause better changes; and consideration about the risks to be faced by colleagues and organizations of whistleblowers (Bok, 2011). It is bad to do whistleblowing by not considering several considerations mentioned above (Gökçe, 2013).

Another thing that drives more people to report illicit actions is the existence of institutional and legislative reforms to combat the acts of retaliation by the law bodies (Gökçe, 2013). Miceli and Dozier (1985) said that the extent of one's moral reasoning could affect whistleblowing intentions. In the research of Rest and Narvaez (1994), it was found that the higher of one's level of reasoning, the greater possibility of the person doing the right thing.

\subsection{Cultural Orientation}

Culture creates an identity and value in one's mindset to do things within his organization that, in turn, will influence important decisions that are taken (Nolan, 2002). From this theory, it can be said that people believe culture has good things to look after, and that can be applied in the daily life of people, which in turn will affect their thinking patterns, ways of their work, and in making of their decisions. Dalton and 
Radtke (2013) provide empirical findings that an organization's ethical environment increases whistleblowing intention. Organizational environmental conditions can also be in the form of restricted stock compensation, which increases reporting intention (Rose, Brink, and Norman, 2016). Organizational justice also causes whistleblowing intention to increase when fraud occurs (Seifert, Sweeney, Joireman, and Thornton, 2010). The organizational environment can also be a culture that exists in an organization.

There are two cultural dimensions in organizations and societies: individualism and collectivism (Morris et al., 1993). The culture of individualism refers to personal interests, in which the pursuit of personal interests may be contrary to collective interests. In an individualistic culture, the motivation that often arises is self-interestoriented, and individuals with this motivation contribute to groups to gain recognition from the groups and benefit from others' efforts (Morries et al., 1993). On the other hand, the culture of collectivism emphasizes the interests of a group, working together, sharing, the harmony of a group, and concern for a group's welfare. Members of a collectivist culture also believe that they are entirely part of a group so that any benefits should be shared for all because they consider that all members are responsible for contributing and sharing. Fiske et al. (1998) argued that individuals in an individualistic culture are considered as people who strive to make themselves in a good position while individuals in a collectivist culture focus more on their relationships with people in their community.

\subsection{Whistleblowing Reporting Channels}

A reporting channel is access used by a whistleblower to show his whistleblowing intention. The purpose of a reporting channel is to make it easy for a whistleblower to prove his whistleblowing intention. Using reporting channels, whistleblowers can choose which channel they consider safe for them to report a fraud. Some research distinguishes external and internal whistleblowing (Kaptein 2011; MacNab and Worthley, 2008; Miceli, Near, and Dworkin, 2008; Zhang, Ciu, and Wei 2009). Internal reporting channels require clear formal disclosure procedures (Barnett et al. 1993). By 
strengthening the internal reporting process, the organization can respond to wrongdoing quickly, and the wider community does not know it (Miceli et al. 2009).

Park et al. (2008) said that there are three dimensions of reporting channels that can help whistleblowers report fraud, one of which is the formal and informal dimensions. The formal reporting channel is an access that is in line with provisions or standards within an organization to report fraud. In contrast, the informal reporting channel is accessed in an organization that individuals can use to report frauds to parties who are believed to be able to eradicate the fraud actions - individuals who decide as whistleblowers calculate the costs and benefits of reporting internally through formal channels. For individuals who decide to whistle to an external party, they have the following characteristics: a shorter tenure in an organization, are more successful in changing organizational practices and have more significant evidence of wrongdoing (Dworkin and Baucus, 1998), but at the same time have the potential to be subject to retaliation (Mesmer -Magnus and Viswesvaran, 2005). The formal channels are chosen as internal reporting mechanisms also tend to be designed anonymously to avoid retaliation. Gao, Greenberg, and Wong-On-Wing (2015) provide empirical findings that whistleblowing intention will be higher when reporting is designed anonymously.

\subsection{The Relationship between Cultural Orientation and Whistleblowing Intention}

Anything related to culture helps humans to coordinate their social behavior (Cronk, 2016). From this theory, it can be said that an individual's culture can determine whether the individual to have whistleblowing intention or not. Research by Park et al. (2008) found that there is an influence of cultural orientations on whistleblowing attitudes, both in individualism and collectivist cultures.

Schwartz (1990) said that in a collectivist culture, the goals of a group are the priority, and personal goals are ignored to achieve the group's goals. On the other hand, the culture of individualism prioritizes personal interests over collective interests. Morris et al. (1994) said that the relation is very important in a collectivist culture, even when the costs incurred are greater than the benefits. While the culture of individualism overrides relation when the costs incurred are greater than the benefits. 
The research of Brody et al. (1998) found that the culture of collectivism is a culture that disagrees with the existence of whistleblowing because whistleblowing is regarded as breaking up the unity of an organization when his co-workers report an employee who commits fraud. Keenan (2007) said that individuals who believe in the culture of collectivism do not agree with the existence of whistleblowing. The theory put forward by Keenan is also supported by the research done by Cheng, Karin, and Lin (2015), which states that the intention of individuals in a culture of individualism to do whistleblowing is more likely higher than that of individuals in a culture of collectivism. Based on the above theories and researches, the first hypothesis can be formulated as follows:

H1: Individuals in an individualistic culture have greater whistleblowing intentions than individuals in a collectivist culture.

\subsection{The Relationship of Whistleblowing Reporting Channels and Whistleblowing}

\section{Intentions}

Reporting channels aim to make it easier for whistleblowers to submit their reports of fraud so that whistleblowers can choose the existing whistleblowing reporting channels to report fraud. The results of Park et al. (2008) research show that most people choose formal reporting channels than informal reporting channels to report fraud. It is because companies or organizations provide facilities for whistleblowers so that whistleblowers are confident that they get support to report fraud. Formal reporting channels can be carried out with the help of hotlines and anonymous to avoid retaliation. Informal reporting channels tend to be done by informing authorities both internally and externally without going through certain media, for example, by reporting fraud information that is known directly.

Kaplan, Pany, Samuels, and Zhang (2009), Brink et al. (2013), Brink et al. (2017) reported that an internal hotline was chosen by individuals who knew fraud rather than an external hotline. Meanwhile, Zhang, Pany, and Reckers (2013) provide empirical findings that the whistleblowing intention will be greater when the reporting hotline is done externally rather than internally. Hotline-based reporting to both internal and 
external is a formal reporting channel that can increase whistleblowing intention. Based on the theories and previous researches, the second hypothesis can be formulated as follows:

H2: Individuals who use formal reporting channels have greater whistleblowing intentions than individuals who use informal reporting channels.

\subsection{The Interaction of Cultural Orientation, Whistleblowing Reporting Channel and} Whistleblowing Intention

Whistleblowing intention is also potentially influenced by two conditions: channel and cultural orientation, that interact with each other. The research of Park et al. (2008) found that that one's attitude towards whistleblowing is influenced by cultural orientations, countries of origin, reporting channels. Channel reporting is an important factor for dealing with retaliation that may be received by whistleblowers. Kaplan et al. (2015), Utami, Jori, and Hapsari (2018) provide findings that reporting channels influence whistleblowing intention. The whistleblowing process begins with individual witnessing knowing misconduct that occurs in the organization, and reporting to internal and external parties (Lee and Xiao 2018).

Whistleblowing intention is greater when the external hotline reporting line is compared to when it is internally. After whistleblowing is carried out, the organization will react and respond to the whistleblowing report (Near and Miceli, 2016). Reporting channels have the potential to increase whistleblowing intention depending on the cultural orientation that exists in an organization. Thus, there are interactions between reporting channels and cultural orientation that affect whistleblowing intention. Based on the theories mentioned above and researches, the third hypothesis can be formulated as follows:

H3: There is an interaction between cultural orientation and whistleblowing reporting channel on whistleblowing intention. 


\section{Research Method}

This research used a study design of $2 \times 2$ experimental between-subjects factorial design. The independent variables are the cultural orientation of individualism, collectivism, and reporting channels consisting of formal and informal channels. Meanwhile, the dependent variable is whistleblowing intention. The experimental subjects were accounting students at two private universities, namely in Central Java and Bali. This research uses two different campuses because the purpose of experimental research is to test causality (internal validity) and not generalize (external validity). The selected accounting students are those who have taken the Auditing course, with the hope of understanding fraud and anti-fraud strategies. The research of Exadaktylos et al. (2012) found that there were no different results between student and non-student subjects. However, the result would be more accurate when the subjects were chosen rather than the subjects voluntarily answer questions. Subjects in this research experiment are divided into four different groups, based on four cultural conditions and reporting channels with different simulations to test the causality of cultural orientations and reporting channel choices that influence whistleblowing intentions. The experiment matrix of this research is shown in table 1.

Table 1.

Research Experiment Matrix

Reporting Channel

\begin{tabular}{llll} 
& & Formal & Informal \\
\cline { 3 - 4 } & Individualism & Group 1 & Group 2
\end{tabular}

Cultural Orientation

Collectivism Group $3 \quad$ Group 4

The subjects will act as an assistant procurement manager at Merak Textile Company. In this case, the assistant knows that the manager of goods procurement masterminded a bribery case involving a dye vendor to manipulate the price of the item to be $15 \%$ higher. The $5 \%$ is then given to the dye vendor in return. In this condition, 
the subjects who have a cultural orientation of individualism and collectivism can report this act of fraud. The subjects have a choice to do whistleblowing using two reporting channels, namely, formal and informal reporting channels.

At the first stage, all subjects are divided into four groups randomly, based on individualism and collectivism cultures with formal and informal reporting channels. Each group will be given a treatment module. In the second stage, the subjects who have been grouped into four cultural groups with reporting channels will be separated according to the treatment module given to them. In the third stage, the subjects will be given modules following the manipulation of situations in the treatment module.

In the fourth stage, each subject will be given time to fill out the information about the subject. At the fifth stage, each subject must answer a general question about the audit to know the subject's knowledge about the audit, which will affect his answer to the simulation questions. At the sixth stage, each subject will act as an assistant procurement manager who conducts whistleblowing in the condition of each person's culture and their reporting channels. At the seventh stage, the modules that have been filled out by subjects that contain manipulation of their cultures will be collected, and subjects will be returned to their original conditions.

\subsection{Analysis Techniques}

The analysis of the first stage will test each subject by performing a test of manipulation checking, aiming to determine the subject's understanding of the manipulation given. One Way Analysis of Variance (ANOVA) is used to test the effectiveness of randomization and subject description with a purpose to determine the characteristics of subjects that will influence their decision making. The independent sample T-test is used to test the first and second hypotheses. In contrast, the third hypothesis is tested using Two Way ANOVA to determine whether there is an interaction between independent variables and whistleblowing intention. 


\section{Results and Discussion}

\subsection{Overview of Experimental Subjects}

Experiments were held at the accounting department at two private universities in Central Java and Bali province. The experimental subjects were accounting students who have taken auditing courses. Subjects who passed the test of the five questions of manipulation regarding their roles in a company and for the manipulation given were 130 of 140 students. The result of the manipulation check is 81 subjects passed and continue to hypothesis testing. The characteristics of subjects are based on gender, age, grade point average, and semester. The profile of subjects who have participated in this research is shown in Table 2.

Table 2.

Subject Profiles

\begin{tabular}{|l|c|c|}
\hline Information & Total & Percentage \\
\hline Gender & & $77.8 \%$ \\
\hline Female & 63 & $22.2 \%$ \\
\hline Male & 18 & $87.6 \%$ \\
\hline Age & 71 & $12.3 \%$ \\
\hline $20-21$ & 10 & $11.1 \%$ \\
\hline $22-25$ & & $76.5 \%$ \\
\hline Grade Point Average (GPA) & 9 & $12.3 \%$ \\
\hline$<3.00$ & 62 & $37 \%$ \\
\hline $3.00-<3.5$ & 10 & $62.9 \%$ \\
\hline$\geq 3,5-4$ & & \\
\hline Semester & 30 & \\
\hline 6 & 51 & \\
\hline $7-8$ & & \\
\hline
\end{tabular}

Table 2 shows that 63 subjects are female (77.8\%), while only 18 subjects are male (22.2\%). Seventy-one subjects at the age of 21-22 years (87.6\%) and 11 subjects were 22-25 years (12.3\%). Nine subjects have GPA at the range of 2.01-2.99 (11.1\%), 62 subjects have GPA at the range of 3.00-3.49 (76.5\%), and ten subjects have GPA at the range of $\geq 3.5(12,3 \%)$. The majority of subjects were studying in semester 6 , with 30 (37\%) and semesters 7-8 totaling 51 (62.9\%).

Each subject in this study plays a role as an assistant procurement manager in Merak Textile Company. Each subject learned that the manager was behind the bribery 
case involving a vendor of fabric dye. In this situation, the subject has individualism and collectivism cultural orientations and reporting channels to determine the extent of the subject's intention to report a fraud. In the first stage, subjects were grouped into four groups with different treatments. Subjects were given manipulation with different cultural orientations and reporting channels. Next, the subjects were asked to answer questions about information following the treatment of each group. The subjects were asked to state the potential for reporting a fraud occurring in a company based on this information.

\subsection{Checking of Manipulation}

The value of 55 for theoretical value results from the checking of manipulation for cultural orientations and reporting channels. From the theoretical limit, it can be concluded that manipulation is successful if the culture of individualism and formal reporting channels get a value larger than 55 and vice versa if the culture of collectivism and informal reporting channels get a value below 55 .

Table 3.

Results of Manipulation Checking for All Treatments

\begin{tabular}{|c|l|c|c|c|}
\hline \multirow{4}{*}{ Variable } & \multicolumn{2}{|c|}{ Theory } & \multicolumn{2}{c|}{ Fact } \\
\cline { 2 - 5 } & Range & Median & Range & Mean \\
\hline \begin{tabular}{c} 
Cultural Orientation \\
Individualism \\
Collectivism \\
Reporting Channel \\
Formal \\
\cline { 2 - 5 } \\
\cline { 2 - 5 }
\end{tabular} & $10-100$ & 55 & $70-100$ & $85.33 \%$ \\
\cline { 2 - 5 } & $10-100$ & 55 & $10-70$ & $42.22 \%$ \\
\cline { 2 - 5 } & $10-100$ & 55 & $50-100$ & $85.00 \%$ \\
\cline { 2 - 5 } & $10-100$ & 55 & $30-100$ & $57.84 \%$ \\
\hline
\end{tabular}

Table 3 shows the subject in the orientation of individualism culture is at a scale of 70-100 that gives a mean of 85.33, which is higher than the theoretical mean of 55 . In contrast, the subject in the orientation of collectivism culture is at a scale of 10-70 that gives a mean of 42.22 , which is lower than the median value. The subject in the 
formal reporting channel is at a scale of 50-100 that gives a mean of 85.00 , which is higher than the median value. The subject in the informal reporting channel is at the mean of 57.84, which is slightly higher than the median value.

Based on the manipulation checking results, it can be concluded that all subjects receive manipulation treatments following their cultural orientations and reporting channels. Thus, from these results, it can be continued to the next test.

\subsection{Randomization Testing}

Before entering the hypothesis testing stage, randomization testing must be performed first to test the demographics of the subject's profile using the One Way Anova test. This test was conducted to determine whether demographic factors influence decision making.

Table 4.

Anova One Way Test Results

\begin{tabular}{|c|c|c|c|}
\hline & Mean Square & Sig. & Information \\
\hline \multicolumn{4}{|l|}{ Gender: } \\
\hline Between Groups & 0,261 & 0,134 & No Influence \\
\hline Within Groups & 0,164 & & \\
\hline \multicolumn{4}{|l|}{ Age: } \\
\hline Between Groups & 0,388 & 0,699 & No Influence \\
\hline Within Groups & 0,548 & & \\
\hline \multicolumn{4}{|c|}{ Grade Point Average (GPA): } \\
\hline Between Groups & 0,229 & 0,481 & No Influence \\
\hline Within Groups & 0,238 & & \\
\hline \multicolumn{4}{|l|}{ Semester: } \\
\hline Between Groups & 0,433 & 0,200 & No Influence \\
\hline Within Groups & 0,306 & & \\
\hline
\end{tabular}


Based on the demographic indicators using the four available characteristics, all of them do not meet the significance value (Sig), which is smaller than alpha (0.05), so it is concluded that the four characteristics do not affect the decision making to do whistleblowing by the assistant procurement manager. So randomization testing is said to be effective because it does not affect decision-making and the only treatment that affects whistleblowing intentions.

\subsection{Hypothesis Test 1: The Relationship between Cultural Orientation and Whistleblowing}

In this research, hypothesis 1 states that a subject who has an orientation of individualistic culture will have a higher whistleblowing intention than a subject who has an orientation of collectivist culture. The tests were conducted using the test of Sample T-test on groups 1 and 2 who were in the orientation of individualism culture and groups 3 and 4 who were in the orientation of collectivist culture.

Table 5.

Results of Hypothesis Testing 1

\begin{tabular}{|c|c|c|c|c|}
\hline & Mean & Std Deviation & t & Sig. (2-tailed) \\
\hline Cultural Orientation & \multicolumn{3}{|l|}{} \\
\hline Individualism & 85.33 & 9.90 & \multirow{2}{|l|}{15.181} & 0.000 \\
\hline Collectivism & 42.22 & 15.51 & & \\
\hline
\end{tabular}

Table 5 shows that the potential for subjects to perform whistleblowing is very large at 85.33 for those with the cultural orientation of individualism. In contrast, the potential to perform whistleblowing is smaller for subjects with the cultural orientation of collectivism, at 42.22. the statistical test results show that the value of Sig. (2-tailed) equal variances assumed in the t-test for Equality of Means of 0.000 is smaller than alpha (0.05), so it can be concluded that it is significant at a $5 \%$ probability. The results of testing this hypothesis show that there is a great potential for whistleblowing for 
subjects that are oriented toward individualism culture compared to subjects oriented toward collectivist culture.

When an assistant procurement manager is oriented towards the culture of individualism, individual interests, self-recognition, and self-achievement, the assistant will prefer to report the procurement manager. This is because the assistant will get a good self-image by his/her company and because he/she has reported the fraud done by the goods procurement manager that potentially harms the company. The opposite result will be obtained if an assistant procurement manager is oriented towards the culture of collectivism, focusing on relationships, group harmonization, and shared interests. This is because the assistant will prioritize the relationship between himself/herself and the procurement manager to remain intact. The assistant will tend to find solutions for the occurring problems so that his/her intention to do whistleblowing is low.

The results of this hypothesis test are supported by the results of research conducted by Cheng et al. (2015), which show that it is easier for individuals with a culture of individualism to report fraud than individuals with a culture of collectivism. Cheng et al. (2015) also said that individuals with a culture of collectivism have a tendency not to accept whistleblowing as an organizational strategy to be used as an internal control compared to individuals with a culture of individualism.

\subsection{Hypothesis Test 2: The Relationship between Reporting Channels and Whistleblowing}

In hypothesis 2 , it is expected that the subjects will have great potential for whistleblowing using formal reporting channels compared to informal reporting channels. The tests were carried out using the test of Sample T-test on group 1 and group 3 that use formal reporting channels and on groups two and group 4 that use informal reporting channels.

Table 6 shows that the potential for subjects to use the formal reporting channel as a way for conducting whistleblowing is very large at 85.00 , while the potential for subjects to use the informal reporting channel is lower at 57.83. Statistical test results show that the value of Sig. (2-tailed) equal variances assumed in the t-test for Equality 
of Means of 0,000 is smaller than alpha (0.05), so it can be concluded that it is significant at a $5 \%$ probability. The results of testing this hypothesis prove that the great potential for conducting whistleblowing is when subjects use formal reporting channels as a means for conducting their whistleblowing.

Table 6.

Results of Hypothesis Test 2

\begin{tabular}{|c|c|c|c|c|}
\hline & Mean & Std Deviation & t & Sig. (2-tailed) \\
\hline Reporting Channel & \multicolumn{3}{|l|}{} \\
\hline Formal & 85.00 & 11.910 & \multirow{2}{|l|}{8.175} & 0.000 \\
\hline Informal & 57.83 & 17.816 & & \\
\hline
\end{tabular}

This study's results reinforce previous empirical findings that hotline and reporting to internal parties through formal channels will increase whistleblowing intention rather than to external parties (Kaplan, Pany, Samuels, and Zhang, 2009; Brink et al., 2013; Brink et al., 2017). When an assistant procurement manager uses the formal reporting channel as a channel for conducting whistleblowing, which this reporting channel is one of the company's facilities, the assistant will choose to report the procurement manager. This is because the assistant will consider that the company is very supportive of its employees to report any frauds using facilities provided by the company. The assistant will consider that it is safe to conduct whistleblowing when the company takes the initiative to provide facilities. On the contrary, the informal reporting channel relies only on trusted leaders of the company to deal with fraud. Besides, there are no facilities provided by the company for informal reporting channels.

\subsection{Hypothesis Test 3: The Interaction between Cultural Orientation, Whistleblowing Reporting Channels, and Whistleblowing}

Hypothesis three tests the interaction between cultural orientation, whistleblowing channel, and its impact on whistleblowing intention. An interaction test with Two-way Anova is presented in Table 7. 
Table 7.

The Test of Between-Subjects Effect on Hypothesis Data 3

\begin{tabular}{|l|c|c|}
\hline \multicolumn{1}{|c|}{ Source } & Mean Square & Sig. \\
\hline Corrected Model & 6641.257 & 0.000 \\
\hline Intercept & 394201.068 & 0.000 \\
\hline Cultural Orientation & 4178.059 & 0.000 \\
\hline Reporting Channel & & 0.000 \\
\hline Cultural Orientation * Reporting Channel & 15987.106 & 0.006 \\
\hline
\end{tabular}

Table 7 shows that the obtained value of Sig. Corrected Model is 0.000, which is smaller than alpha (0.05), which means cultural orientations, reporting channels, and the interaction between cultural orientation and reporting channel (OB*JP) significantly influence each other on whistleblowing intention so that this Model said to be valid. The Intercept Model shows that the value of Sig. 0.000, which is smaller than alpha (0.05), which means that the whistleblowing changes are influenced by the existence of cultural orientations and reporting channels so that with the influence of these two variables, whistleblowing can change in its value.

Cultural orientation and whistleblowing reporting channels significantly influence whistleblowing intention in the Model. It shows that cultural orientation has a significance value of 0.000 , and the reporting channel has a significance of 0.000 , which is smaller than alpha (0.05). The interaction between cultural orientations and reporting channels shows a significance value of 0.006, which means it is smaller than alpha (0.05). Thus it can be interpreted that the interaction of cultural orientations and reporting channels has a significant influence on whistleblowing intention. Figure 1 illustrates the interaction of cultural orientation and reporting channels. 
Figure 1.

Plot Diagram of Interaction of Cultural Orientation and Reporting Paths

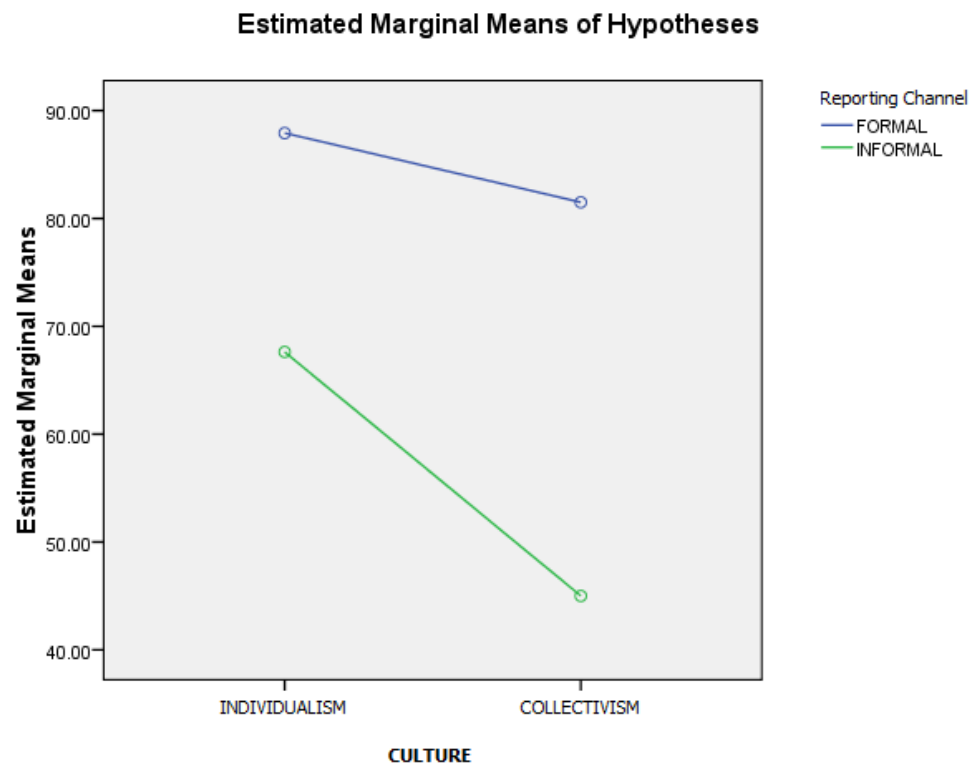

There is an interaction between cultural orientation and reporting channel because cultural orientation is embedded in individuals that will influence their decision to report fraud actions. Therefore it is important to implant a good culture early. Likewise, the reporting channel influences individuals to report because they will see that there is easy and safe access through the channel provided by an organization to help them report fraud actions. This finding is in line with Zhang et al. (2013), which shows an interaction effect between previous whistleblowing outcomes, reporting channels, and personal activity scale. The individual environment shows that the individual is more responsive to do whistleblowing when he knows of the existence of misconduct in the organization and supported by an informal channel of whistleblowing.

\section{Conclusion, Implication, and Limitation}

\subsection{Conclusion}

This research examines whether cultural orientation and reporting channels significantly influence individuals to do whistleblowing. The results of this research can 
be concluded that, first, cultural orientation significantly influences subjects' intention to do whistleblowing. The most significant cultural orientation for conducting whistleblowing is when a subject is in the cultural orientation of individualism, which in this orientation, people refer to prioritize their interests. Meanwhile, subjects in the cultural orientation of collectivism give great importance to the harmonization of relations and shared interests. Thus subjects' intention to do whistleblowing is greater in the cultural orientation of individualism than subjects in the cultural orientation of collectivism.

Second, a reporting channel significantly influences the subjects' intention to do whistleblowing. In this case, subjects prefer formal reporting channels to informal reporting channels. Because the formal reporting channel has clear rules and one of the company's official facilities, subjects consider that this channel is safe to be used than the formal channel. Thus, it can be concluded that the subject's intention will be greater to conduct whistleblowing by using formal channels than informal reporting channels.

Third, there is an interaction between cultural orientation and reporting channel, which means that subject's intention to do whistleblowing is influenced by cultural orientation and depends on the reporting channels they choose. It is because the culture is an internal influence of a person that influences his/her decision to do whistleblowing. Regarding the reporting channel, people will prefer to use a channel that is considered safe to use, and people will inspect first whether a channel is a channel that is officially provided by a company to report fraud.

\subsection{Implication and Limitation}

The limitation of this research is that subjects of this research that took part in the experiment did not fully understand the rules of the experiment and did not properly pay attention to the tutor's directions. Thus, for future research, it is expected that the subjects of the experiment must be conditioned properly before the experiment is performed. The atmosphere of the experiment must be made sure it is conducive to the experiment. By performing this suggestion, hopefully, more accurate results can be obtained from future experiments. 


\section{Reference}

Association of Certified Fraud Examiners. 2017. Survai Fraud Indonesia 2016. Retrieved from ACFE Indonesia Chapter website: https://acfe-indonesia.or.id

Association of Certified Fraud Examiners. 2018. Report to the nation on occupational fraud and abuse. Austin, TX: ACFE

Barnett, T. 1992. A preliminary investigation of the relationship between selected organizational characteristics and external whistleblowing by employees. Journal of Business Ethics, 11 (12): 949-959

Bok, S. 2011. Whistleblowing and professional responsibilities. In Ethics Teaching in Higher Education: 277-295).

Brink, A.G., Lowe, J.D., and Victoravich, L.M. (2013). The effect of evidence strength and internal rewards on intentions to report fraud in the Dodd-Frank regulatory environment. Auditing: A Journal of Practice \& Theory, 32 (3): 87-104

Brody, R. G., Coulter, J. M., and Mihalek, P. H. 1998. Whistleblowing: a cross-cultural comparison of ethical perceptions of U.S. and Japanese accounting students. American Business Review; West Haven, 16(2), 14-21.

Cheng, X., Karim, K. E., and Lin, K. J. 2015. A cross-cultural comparison of whistleblowing perceptions. International Journal of Management and Decision Making, 14(1), 15-31.

Coffin, B. 2003. Trends in corporate fraud. Journal of Risk Management, 50(5), 1-12.

Cronk, L. 2016. Culture's influence on behavior: steps toward a theory. Evolutionary Behavioral Sciences, 11(1): 36-52.

Dalton, D., and Radtke, R.R. 2013. The joint effect of Machiavellianism and ethical environment on whistleblowing. Journal of Business Ethics, 117 (1), 153-172

Dworkin, T.M., and Baucus, M.S. 1998. Internal vs. external whistleblowers: a comparison of whistleblowing processes. Journal of Business Ethics, 17 (12): 1281-1298

Dyck, A., Morse, A., and Zingales, L. 2010. Who blows the whistle on corporate fraud? The Journal of Finance, 65 (6): 2213-2253

Delloite Forensic Center. 2010. Whistleblowing and the new race to report: Delloite Touche Tohmatsu.

Enz, C. A. 1988. The Role of Value Congruity in Intra organizational Power. In Science, Sage Pulications, Inc. 33: 284-304.

Exadaktylos, F., Garza, P. B., and Espın, A. M. 2012. Experimental subjects are not different. Scientific Reports, 3(1213), 1-6. 
Fiske, A. P., Kitayama, S., Markus, H. R., and Nisbett, R. E. 1998. The cultural matrix of social psychology. In D. T. Gilbert, S. T. Fiske, and G. Lindzey (Eds.), The handbook of social psychology (pp. 915-981). New York: U.S.: McGraw-Hill.

Gökçe, A. P. D. A. T. 2013. Teachers, value orientations as determinants of preference for external and anonymous whistleblowing the department of educational sciences. International Journal of Humanities and Social Science, 3(4), 163-173.

Gao, J. Greenberg, R., and Wong-On-Wing, B. 2015. Whistleblowing intention of lower-level employees: The effect of reporting channel, bystanders, and wrongdoers power status. Journal of Business Ethics, 126 (1): 85-99

Gao, J., and Brink, A.G. 2017. Whistleblowing studies in accounting research. Journal of Accounting Literature 38: 1-13

Hoffman, W. M., and McNulty, R. E. 2014. A business ethics theory of whistleblowing: responding to the $\$ 1$ trillion question. Part of Whistleblowing in Defense of Proper Action, 18, 45-60.

Hofstede, G. 1980. Culture's Consequences: International Differences in Work-Related Values. Sage, Beverly Hills, CA: Sage Pulications, Inc.

House, R., Watt, A., and Williams, J. M. 2004. Teaching Enron: rhetoric and ethics of whistleblowing. IEEE Transactions on Professional Communication, 47(4), 244-255.

Kaplan, S.E., Pany, K. Samuels, J.A. and Zhang, J. 2009. An examination of the effects of procedural safeguards on intentions to anonymously report fraud. Auditing: A Journal of Practice \& Theory, 28 (2): 273-288

Kaplan, S.E., Pope, K.R., and Samuels, J.A. 2015. An examination of anonymous and nonanonymous fraud reporting channels. Advances in Accounting, 28 (1): 88-95

Kaptain, S.E., and Schultz, J. J. 2007. From inaction to external whistleblowing: the influence of organizations' ethical culture on employee responses to observed wrongdoing. Journal of Business Ethics, 98 (3): 513-530

Kaptain, M. 2011. From inaction to external whistleblowing: The influence of organizations' ethical culture on employee responses to observed wrongdoing. Journal of Business Ethics, 98(3): 513-530.

Keenan, J. P. 2007. Comparing Chinese and American managers on whistleblowing. Employee Responsibilities and Rights Journal, 19(2): 85-94.

KPMG. 2010. Fraud and misconduct survey: Australia and New Zealand

Lee, G., and Xiao, X. 2018. Whistleblowing on accounting-related misconduct: A synthesis of the literature. Journal of Accounting Literature, 41: 22-46 
Lestari, R., and Yaya, R. 2017. Whistleblowing dan Faktor-Faktor Yang Mempengaruhi Niat Melaksanakannya Oleh Aparatur Sipil Negara. Jurnal Akuntansi, 21(3): 336.

MacNab, B. R., and Worthley, R. 2008. Self-efficacy as an intrapersonal predictor for internal whistleblowing: A US and Canada examination. Journal of Business Ethics, 79 (4): 407-421

Miceli, M. P., and Dozier, J. B. 1985. Potential Predictors of Whistle-Blowing: A Prosocial Behavior Perspective. Academy of Management Review, 10(4), 823-836.

Miceli, M. P., and Near, J. P. 1992. Blowing the Whistle: The Organizational and Legal Implication for Companies and Employees. In New York: Lexington Books.

Miceli, M. P., Near, J. P., and Schwenk, C. R. 2006. Who Blows the Whistle and Why? In Industrial and Labor Relations Review, 45: 113

Miceli, M.P., Near, J.O., and Dworkin, T.M. 2008. Whistleblowing in organizations. New York: Routledge, Taylor and Francis Group.

Mesmer-Magnus, J., and Visvwesvaran, C. 2005. Whistleblowing in organizations: An examination of correlates of whistleblowing intention, actions, and retaliation. Journal of Business Ethics, 62 (3): 227-297

Morris, M. H., Davis, D. L., and Allen, J. W. 1994. Fostering Corporate Entrepreneurship: CrossCultural Comparison of the Importance of Individualism Versus Collectivism. Journal of International Business Studies, First Quarter, 25(1), 65-89.

Near, J. P., and Miceli, M. P. 1987. Whistle-Blowers in Organizations: Dissidents or Reformers? JAI Press.

Near, J.P., and Miceli. P.M. 1995. Effective-whistleblowing, Academy of Management Review, 20 (3): 679-708

Near, J.P., and Miceli, M.P. 2016. After the wrongdoing: What managers should know about whistleblowing. Business Horizons, 59 (1): 105-114

Nolan, R. W. 2002. Development Anthropology. New York: Westview Press.

Park, H., Blenkinsopp, J., Oktem, M. K., and Omurgonulsen, U. 2008. Cultural orientation and attitudes toward different forms of whistleblowing: a comparison of South Korea, Turkey, and the U.K. Journal of Business Ethics, 82(4): 929-939.

Pascoe, J., and Welsh, M. 2010. Whistleblowing, Ethics and Corporate Culture: Theory and Practice in Australia. Common-Law World Review, 40(2): 144-173.

Rest, J. R., and Narvaez, D. 1994. Moral Development in the Professions: Psychology and Applied Ethics. Lawrence Erlbaum Associates, Inc.

Rose, J.M., Brink, A.G., and Norman, C.S. 2017. The effect of compensation structures and monetary rewards on managers' decisions to blow the whistle. Journal of Business 
Ethics: 853-862

Schmidt, M. 2005. Whistleblowing regulation and accounting standards enforcement in Germany and Europe - An Economic Perspective. International Review of Law and Economics, 25(2): 143-168.

Schwartz, S. H. 1990. Individualism-collectivism: critique and proposed refinements. Journal of Cross-Cultural Psychology, 21(2): 139-157.

Seifert, D. L., Sweeney, J, T., Joireman, J., and Thornton, J.M. 2010. The influence of organizational justice on accountant whistleblowing. Accounting, Organization and Society, 35(7): 707-103

Setianto, V. Y., Utami, I., and Novianti, S. 2016. Whistleblowing dalam tekanan ketaatan dan kepercayaan pada pimpinan. Jurnal Ekonomi dan Bisnis, 19 (3), 485-510.

Tavakoli, A. A., Keenan, J. P., and Crnjak-Karanovic, B. 2003. Culture and whistleblowing an empirical study of Croatian and the United States Managers Utilizing Hofstede's Cultural Dimensions. Journal of Business Ethics, 43, 49-64.

Trongmateerut, P., and Sweeney, J. T. 2013. The influence of subjective norms on whistleblowing: a cross-cultural investigation. Journal of Business Ethics, 112(3), 437451.

Utami, I., Jori, A., and Pesudo, D. A. 2017. Sudikah akuntan mengungkap aib kecurangan? Jurnal Akuntansi Multiparadigma. 8 (3): 458-469

Vinancia, C. V., Utami, I., and Mohamed. 2019. Personal cost of reporting and status of wrongdoers: experimental study of whistleblowing intention. Asia-Pacific Management Accounting Journal, 14 (3): 81-103

Zhang, J., Chiu R., and Wei, L. (2009). Decision-making process of internal whistleblowing behavior in China: empirical evidence and implications. Journal of Business Ethics, 88 (1): $25-41$

Zhang, J., Pany, K., and Reckers, P.M, (2013), Under which conditions are whistleblowing best practices best? Auditing: A Journal of Practice and Theory, 32 (3): 171-181 